\title{
PENINGKATAN KETERAMPILAN MOTORIK HALUS ANAK USIA DINI (AUD) MELALUI KEGIATAN MERONCE DI TAMAN KANAK-KANAK AISYIYAH II KOTA BIMA
}

\author{
Retnoningsih ${ }^{1} \mathcal{E}$ Sri Jamilah \\ Pengajar pada Institut Agama Islam (IAI) Muhammadiyah Bima \\ niengsihmarsyaf91@gmail.com
}

\section{ABSTRAK}

Penelitian tindakan ini berjudul Peningkatan Ketrampilan Motorik Halus Anak Usia Dini Melalui Kegiatan Meronce di Taman Kanak-Kanak Aisyiyah II Kota Bima. Dengan tujuannya adalah untuk menggambarkan proses dari hasil belajar melalui kegiatan meronce dalam upaya meningkatkan keterampilan motorik halus anak usia dini di Taman Kanak-Kanak Aisyiyah II Kota Bima.

Model penelitian yang digunakan adalah metode action research.dari Kemmis dan Taggart dengan meliputi tahap-tahap: a) perencanaan (planning), b) tindakan (acting), c) pengamatan (observing), d) refleksi (reflecting), dengan subjek penelitian sebanyak 15 orang anak, pada kelompok A Taman Kanak-Kanak Aisyiyah II Tolobali Kota Bima. Teknik pengumpulan data yang digunakan adalah wawancara, observasi dan dokumentasi, sedangkan teknik analisis data yang digunakan adalah analisis data kualitatif dan kuantitatif.

Hasil penelitian menjelaskan bahwa keterampilan motorik halus anak Usia Dini kelompok A meningkat, yang dilihat dari kenaikan skor klasikal dari kegiatan pra tindakan $26,8 \%$. Setelah diadakan siklus I menjadi meningkat 34,8\%, dan siklus II meningkat menjadi $40 \%$. Kegiatan meronce dapat menjadi alternatif mengajarkan keterampilan motorik halus untuk anak usia dini.

Kata Kunci: Motorik halus, Anak Usia Dini (AUD), dan meronce

${ }^{1}$ Retnoningsi. Merupakan staff pengejar pada Institut Agama Islam Muhammadiyah Bima

Jurnal Pelangỉ Jurnal pemikiran dan penelitian pendidkan Islam anak Usia Dini 


\section{PENDAHULUAN}

Pendidikan merupakan salah satu kebutuhan hidup yang sangat penting saat ini. Hal ini sangat mendasar mengingat pendidikan dijadikan sebagai salah satu tolak ukur kesejahteraan manusia. Berkualitas tidaknya seseorang dipengaruhi sejauh mana kualitas pendidikan yang didapatkan di bangku sekolah atau masyarakat. Dalam arti sempit, pendidikan identik dengan persekolahan tempat pendidikan dilakukan dalam bentuk kegiatan pembelajaran yang terprogram dan terencana secara formal. "Pendidikan akan membentuk pengalaman belajar baik yang berlangsung dalam lingkungan keluarga, sekolah, maupun masyarakat untuk mengembangkan perkembangan seoptimal mungkin sejak lahir sampai akhir hayat". ${ }^{2}$

Salah satu implementasi dari hak ini, setiap anak berhak memperoleh pendidikan dan pembelajaran dalam rangka pengembangan pribadinya, sesuai dengan minat dan bakat anak. Pendidikan anak usia dini dapat disingkat PAUD. Pendidkan Anak Usia Dini (PAUD) adalah suatu upaya pembinaan yang ditujukan bagi anak melalui pemberian rangsangan pendidikan untuk membantu pertumbuhan dan perkembangan jasmani dan rohani anak, agar anak memiliki kesiapan dalam memasuki pendidikan lebih lanjut. Pendidkan Anak Usia Dini (PAUD) merupakan salah satu bentuk penyelenggaraan pendidikan yang meniti beratkan pada peletakan dasar kearah pertumbuhan dan perkembangan fisik (koordinasi motorik halus, dan kasar), kecerdasan (daya pikir, daya cipta,kecerdasan emosi, kecerdasan spiritual), sosial emosional (sikap dan perilaku serta agama), bahasa dan komunikasi, sesuai dengan keunikan anak usia dini dan tahap-tahap perkembangan yang dilalui oleh anak usia dini. Kunci dari pertumbuhan dan perkembangan anak usia dini terdapat pada kata stimulasi dan perangsangan. Melalui stimulasi dan perangsangan, anak usia dini dapat menumbuh kembangkan setiap potensi yang ada dalam dirinya.

Hal ini harus dibentuk oleh pengasuh, guru dan keluarga yang selama ini bergaul bersama anak usia dini. Pertumbuhan dan perkembangan anak usia dini mencakup dua hal yang berbeda tetapi saling berkaitan dan sulit untuk dipisahkan. Salah satu aspek perkambangan anak

${ }^{2}$ Wiyani Ardy Novan dan Barnawi. 2012. Format PAUD. Jogjakarta: Ar.Ruzz Media 
usia dini yang harus dikembangkan adalah keterampilan motorik halus. Keterampilan motorik halus anak usia dini sangat penting untuk dikembangkan karena motorik halus merupakan salah satu aspek kognitif dalam perkembangan anak-anak usia dini.

Agar perkembangan anak usia dini didik di Pendidkan Anak Usia Dini (PAUD) dapat meningkat, maka diperlukan dukungan berbagai fasilitas, sarana, dan prasarana, seperti media dan alat peraga yang memadai atau APE (Alat Permainan Edukatif). Perkembangan anak usia dini berlangsung secara optimal sesuai dengan tingkat perkembangan yang dicapai pada suatu tahap diharapkan meningkat secara kuantitatif maupun kualitatif pada tahap selanjutnya. Terdapat perbedaan perkembangan di setiap individual, karena terdapat pengaruh beberapa faktor internal maupun eksternal sehingga setiap anak usia dini memiliki karakter yang unik dan berbeda meskipun tetap berdasarkan atas pola perkembangan umum. Untuk mencapai tingkat perkembangan yang optimal dibutuhkan keterlibatan orang dewasa untuk memberikan rangsangan atau stimulasi.

Masa kanak-kanak juga merupakan salah satu faktor utama dalam pembentukan karakter dan penunjang kesuksesan karena ketika tumbuh dan berkembang terdapat serangkaian tahapan tertentu yang akan dicapai, baik dari segi perubahan fisik dan psikis maupun perkembangan keterampilan motorik.

Anak pada usia dini ini dapat terlihat pada sekumpulan anak didik yang terdapat dihampir semua Taman Kanak-kanak (TK). Dalam standar kompetensi kurikulum Taman Kanak-kanak tercantum bahwa tujuan pendidikan di taman kanak-kanak adalah membantu mengembangkan berbagai potensi anak usia dini baik psikis dan fisik yang meliputi moral dan nilai-nilai agama, sosial emosional, kognitif, bahasa, fisik motorik, kemandirian dan seni untuk memasuki pendidikan dasar. ${ }^{3}$

Kecenderungan anak usia dini untuk berfikir sederhana dan tidak mudah menerima sesuatu yang majemuk menuntut anak untuk berfikir logis sehingga sangat dibutuhkan media serta metode yang dapat berpengaruh pada perkembangan motorik halus anak usia dini dalam periode perkembangannya.

${ }^{3}$ Bambang Sujiono, dkk., Metode Perkembangan Fisik, ( Jakarta: Universitas Terbuka, 2010 ), 2.10.

Jurnal Pelang̉i Jurnal pemikiran dan penelitian pendidkan Islam anak Usia Dini 
Dengan demikian para guru khususnya guru Pendidkan Anak Usia Dini (PAUD) agar lebih kreatif dalam melakukan langkah yang tepat untuk menerapkan suatu media pembelajaran di kelas. Pada akhirnya akan tercapai tujuan pembelajaran yang telah direncanakan, dengan cara mengadakan evaluasi terhadap metode pembelajaran yang dilakukan selama ini.

Berdasarkan hasil observasi awal pada anak usia dini kelompok A Taman Kanak-Kanak Aisyiyah II Tolobali Kota Bima tahun 2018 yang telah dilakukan oleh peneliti, terdapat 10 dari 15 anak usia dini memiliki keterampilan motorik halus yang masih rendah. Pada saat melaksanakan kegiatan belajar anak-anak usia dini masih banyak yang belum lancar menggerakkan motorik halusnya dan masih dibantu oleh guru. Dari kegiatan ini peneliti melihat ada beberapa anak usia dni yang masih belum lancar menggerakan motorik halus dan masih dibantu oleh gurunya.

Hasil observasi awal tersebut, maka peneliti berkolaborasi dengan guru membuat penelitan tindakan untuk peningkatkan ketempilan motoik halus anak usia dini kelompok A Taman Kanak-Kanak Aisyiyah II Tolobali Kota Bima tahun 2018, dengan menggunakan kegiatan meronce mulai dari media dan cara melaksanakannya dimodifikasi untuk kemampuan motorik halus anak usia dini kelompok A Taman KanakKanak Aisyiyah II Tolobali Kota Bima.

Perkembangan keterampilan motorik pada anak usia dini meliputi motorik kasar dan halus. Bahwasanya tingkat pencapaian perkembangan motorik halus anak usia 4-5 tahun dalam aspek perkembangan kognitif, yaitu:

1. Anak mampu mengelompokkan;

2. Memasangkan benda yang sama dan sejenis atau sesuai pasangannya;

3. Menyusun kepingan hingga menjadi bentuk utuh, dan

4. Membedakan beragam ukuran;

Anak pada usia ini dapatdilihar pada sekumpulan anak didik yang terdapat dihampir semua Taman Kanak-kanak (TK). Dalam standar kompetensi kurikulum Taman Kanak-kanak tercantum bahwa tujuan pendidikan di taman kanak-kanak adalah membantu mengembangkan berbagai potensi anak baik psikis dan fisik yang meliputi moral dan nilai-nilai agama, sosial emosional, kognitif, bahasa, fisik motorik, 
kemandirian dan seni untuk memasuki pendidikan dasar. ${ }^{4}$

Berdasarkan hasil pengamatan awal pada anak kelompok A Taman Kanak-kanak (TK). Aisyiyah II Tolobali Kota Bima tahun 2018 yang telah dilakukan oleh peneliti, terdapat 10 dari 15 anak memiliki keterampilan motorik halus yang masih rendah. Untuk meningkatkan keterampilan motorik halus anak, usia dini maka telah dilakukan penelitian dengan judul "Peningkatan Keterampilan Motorik Halus Melalui Kegiatan Meronce (Penelitian Tindakan Pada kelompok A Taman Kanak-Kanak Aisyiyah (TK) II Tolobali Kota Bima 2018)". Melalui kegiatan meronce ini, diharapkan anak-anak usia dni dapat menyalurkan perasaannya dan menciptakan keindahan.

\section{Keterampilan Motorik Halus}

Perkembangan motorik halus sangat penting bagi anak usia dini, karena berpengaruh pada segi pembelajaran tersebut seperti menulis, menggunting, menjiplak, mewarnai, melipat, menarik garis dan menggambar. Maka dari itu penguasaan motorik halus penting bagi anak usia dini, karena seiring makin banyak keterampilan motorik yang dimiliki anak usia dini semakin baik pula penyesuaian sosial yang dapat dilakukan anak usia dini serta semakin baik perkembangan anak usia dini.

Keterampilan motorik halus sangat berkaitan dengan berbagai gerakan yang dilakukan oleh anak usia dini dalam masa pertumbuhan dan perkembangannya. Keterampilan motorik halus meliputi otot-otot kecil yang ada di seluruh tubuh, seperti menyentuh dan memegang. ${ }^{5} \mathrm{Hal}$ ini menunjukkan bahwa keterampilan motorik halus merupakan proses memperoleh keterampilan dan pola gerakan yang dilakukan oleh tubuh.

Menurut Anne, V Gormly dan David M. Brodzinsky, keterampilan motorik halus meliputi penggunaan dan kontrol otot yang kecil seperti jari. ${ }^{6}$ Anak usia dini dapat merespon keterampilan motorik halus melalui gerakan-gerakan kecil oleh tubuh yang sedang dilakukannya. Selain itu,

${ }^{4}$ Bambang Sujiono, dkk., Metode Perkembangan Fisik, ( Jakarta: Universitas Terbuka, 2010 ), 2.10.

${ }^{5}$ Desmita,PsikologiPerkembangan,(Bandung:PT Remaja Rosdakarya, 2008)

${ }^{6}$ Anne V. Gormly and David M. Brodzinsky, lifespan Human Development, Fifth Edition (New York: Harcourt Brace Jovanpviich CollegePublishers,1993: 167)

Jurnal Pelang̉i Jurnal pemikiran dan penelitian pendidkan Islam anak Usia Dini 
Gallahu dan Ozmun juga menyatakan bahwa motorik halus meliputi gerakan yang terbatas dari bagian tubuh dalam hal precise (ketepatan/ ketelitian) dan gerakan manipulatif. ${ }^{7}$

Secara umum, Gallahu menyatakan bahwa yang termasuk dalam gerakan motorik halus adalah menggunting, menulis dan mengetik. Senada dengan pendapat di atas John W Santrok menjelaskan bahwa motorik halus melibatkan gerakan yang diatur secara halus, seperti menggenggam mainan, mengancing baju atau melakukan apapun yang memerlukan keterampilan tangan. ${ }^{8}$ Berarti bahwa kegiatan keterampilan motorik halus anak usai dini lebih terarah pada keterampilan dan aktivitas tangan yang berkoordinasi dengan mata dan gerak jari.

Pendapat lain Diane E Papalia keterampilan motorik halus adalah kemampuan-kemampuan fisik yang melibatkan otot halus serta koordinasi mata dan tangan. ${ }^{9}$ Setiap anak usia dini yang sedang melakukan aktivitas gerak jari-jari tangan, hal ini menunjukkan bahwa terhadap stimulasi tahapan perkembangan motorik keterampilan motorik halus anak usia dini.

Berdasarkan beberapa pendapat para ahli di atas dapat disimpulkan bahwa keterampilan motorik halus adalah keterampilan yang meliputi otot-otot kecil yang ada di seluruh tubuh, terutama otot-otot yang melibatkan koordinasi mata dan tangan.

\section{MERONCE}

Kata meronce berarti: "menyusun benda atau merangkai benda dengan menggunakan seutas tali atau yang lain". ${ }^{10}$ Meronce manikmanik adalah perkembangan manyusun manik-manik menjadi satu dengan menggunakan seutas tali atau benang. Warna manic-manik yang menyala akan menarik minat bagi semua anak usia dini. Setelah manikmanik di rangkai melalui lubang yang ada di tengah manik-manik, maka

${ }^{7}$ Gallahu, David L. dan John C. Oznum. Understanding Motor Development. Boston: MC Graw Hill Ccompanies.1998:20)

${ }^{8}$ Santrok W John Perkembangan Anak, Edisi Kesebelasan Jakarta: Penerbit Erlangga, 2007:16)

${ }^{9}$ Diana E Papalia dkk, Human Development (Perkembangan Manusia) Edisi ke 10 (Salemba Humanika:2009:327)

${ }^{10}$ Dikutip dari: http:/blogspot.com.201 
akan menjadi kalung, gelang, jepit rambut dan kreasi yang lainnya. ${ }^{11}$

Menurut Sumanto, meronce merupakan cara pembuatan benda hias atau benda pakai yang dilakukan dengan menyusun bagian-bagian bahan berlubang atau sengaja dilubangi memakai bantuan benang, tali dan sejenisnya. ${ }^{12}$

Sedangkan menurut Hajar Pamadhi dalam buku seni keterampilan anak, meronce adalah menata dengan bantuan mengikat komponen tadi dengan utas atau tali. Denganikatan teknikiniseseorang akan memanfaatkan bentuk ikatan menjadi lebih lama dibandingkan dengan benda yang ditata. Meronce juga harus mengenal bentuk, warna dan ukuran. ${ }^{13}$

Edy Purwanto yang mengungkapkan bahwa meronce adalah menyusun bahan yang berlubang atau sengaja dilubangi untuk menghasilkan rangkaian. Rangkaian ini dapat digunakan, baik sebagai hiasan maupun benda pakai. ${ }^{14}$

Berdasarkan beberapa pendapat para ahli di atas dapat disimpulkan bahwa meronce adalah pembuatan benda hias yang dilakukan dengan cara menyusun atau merangkai bagian-bagian bahan yang sudah dilubangi untuk membuat benda pakai atau benda hias.

\section{METODE PENELITIAN}

Kegiatan yang dilakukan dalam tahap ini adalah melaksanakan skenario pembelajaran dengan menggunakan strategi pembelajaran kreatif-produktif yang telah direncanakan. Pada setiap siklus penelitian ini terdiri dari 4 kali pertemuan dengan 4 kali evaluasi pada setiap akhir pertemuan. Secara garis besar, tahapan pelaksanaan strategi pembelajaran menggunakan metode pemberian tugas.

Metode yang digunakan adalah action research menggunakan prosedur Kemmis dan MC Taggart, model ini, meliputi tahap-tahap: a)

\footnotetext{
${ }^{11}$ Mirantiyo Yoki. 2012. Teknik Meronce Manik-manik. Tersedia pada http://yokimirantiyo. blogspot.co m/2012/09/teknik-meroncemanik-manik.html. (diakses Tanggal 20 januari 2018).

${ }^{12}$ Ika Setia Endayanti, "Meningkatkan Kemampuan Motorik Halus Melalui Kegiatan Meronce Pada Anak Kelompok Bermain Masjid Syuhada”, ("Skripsi” , Universitas Negeri Yogyakarta, 2013), 33.

${ }^{13}$ Susi Sudaryani, "Penerapan Tehnik Meronce Untuk Mengembangkan Kreativitas Anak Di Kelompok B1 Raudhatul Athfal Babul Janah Bengkulu",("Skripsi", Universitas Bengkulu, 2014), 26.

${ }^{14}$ Mumpuni Arum Bakti, "Peningkatan Keterampilan Motorik Halus Melalui Kegiatan Meronce Menggunakan Tanah Liat Pada Kelompok B TK Yayasan Masyithoh Beran Bugel Kulon Progo", (“Skripsi”, Universitas Negeri Yogyakarta, 2014), 46.
}

Jurnal Pelangi Jurnal pemikiran dan penelitian pendidkan Islam anak Usia Dini 
perencanaan (planning), b) tindakan (acting), c) pengamatan (observing), d) refleksi (reflecting). ${ }^{15}$ Penelitian ini terdiri dari delapan pertemuan persiklus, jika siklus I belum berhasil maka diadakan siklus II, begitu sampai dengan penelitian tersebut dinyatakan berhasil.

Analisis kuantitatif dilakukan untuk melihat perubahan peningkatan kegiatan meronce anak usia dini pada asesmen awal dan asesmen akhir dengan menggunakan prosentase rata-rata setiap aspek kegiatan meronce.

\section{HASIL PENELITIAN}

\section{Ketrampilan Motorik Halus Anak Dengan Kegiatan Meronce}

Fokus penelitian ini adalah melihat hasil perkembangan keterampilan motorik halus anak yaitu penjabaran dari hasil kesimpulan tentang konsep keterampilan motorik halus yaitu otot-otot kecil, dan melibatkan otot halus serta koordinasi mata dan tangan. Selain itu juga, konsep meronce yaitu pembuatan benda hias yang dilakukan dengan cara menyusun atau merangkai bagian-bagian bahan yang sudah dilubangi untuk membuat benda pakai atau benda hias.

Meronce mengajarkan anak tentang keterampilan motorik halus, menyusun benda yang sama, memahami konsep setelah anak usia dini dapat mengenal bentuk, merangkai bentuk. Dalam kegiatan meronce ini diutamakan dalam proses pengembangan keterampilan, tanpa ada pemaksaan karena anak melakukannya dengan senang hati dan mereka ingin melakukannya lagi setiap guru mengajak untuk meronce. Terdapat peningkatan yang diperoleh oleh anak usia dini dalam kegiatan peningkatan keterampilan motorik halus anak usia dini melalui kegiatan meronce dari pra tindakan, siklus I, dan siklus II yang dapat dilihat dari grafik di bawah ini.

\footnotetext{
${ }^{15}$ Kemmis, Stephen and Robin Mc Tanggart, Action Research Planner (Victoria: Deakin University Press,1988)
} 


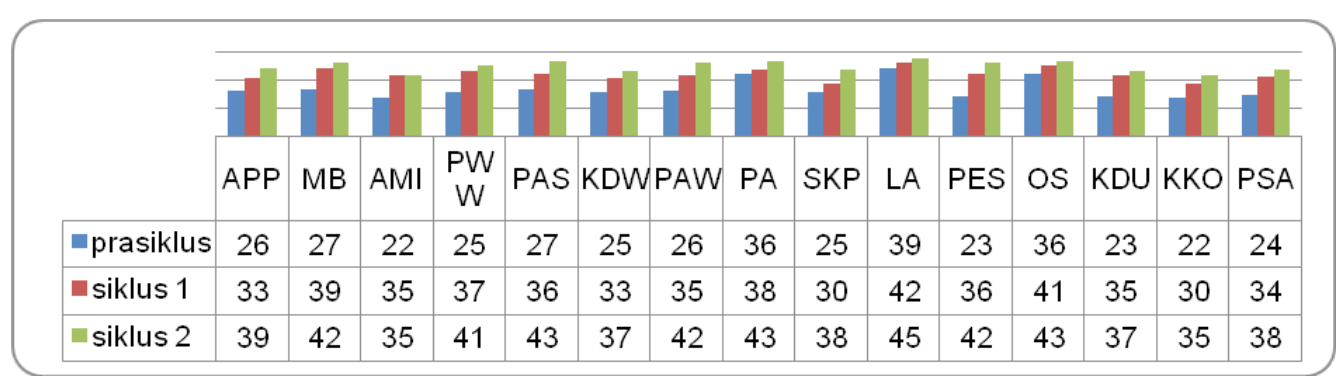

(Gambar 1. Grafik Hasil Penelitian)

Pada siklus di atas dapat dilihat bahwa penelitian ini mengalami peningkatan dalam hasil. Assesmen awal yang dilakukan pada pra tindakan menunjukkan bahwa kemampuan keterampilan motorik halus anak usia dini masih kurang sehingga peneliti melakukan penelitian tindakan untuk peningkatan keterampilan motorik halus menggunakan kegiatan meronce. Peneliti ini menggunakan dua suklus, siklus pertama tingkat keberhasilan klasikal anak usia dini mencapai 34,8\% yang artinya belum mencapai nilai ketentuan klasikal yang disepakati oleh guru dan peneliti, sehingga diperlukan siklus kedua untuk memperbaiki siklus pertama dengan melihat hasil refleksi dari siklus pertama yang menunjukkan bahwa penelitian tindakan ini belum mencapai ketuntasan karena pada aspek kognitif, yaitu anak usia dini belum mampu mengelompokkan, memasangkan benda yang sama dan sejenis atau sesuai pasangannya, menyusun kepingan hingga menjadi bentuk utuh, dan membedakan beragam ukuran.

Pada aspek mampu merangkai bentuk yang sama, memasangkan benda yang sama dan sejenis atau sesuai pasangannya, menyusun kepingan hingga menjadi bentuk utuh, dan membedakan beragam ukuran anak usia dini masih perlu bimbingan guru untuk menyelesaikan kegiatan tersebut. Media pendukung meronce yang digunakan perlu di tambah untuk memberikan daya ketertarikan pada anak usia dni dan membantu anak usia dini tidak cepat bosan. Kegiatan pada media yang dilaksanakan kepada anak usia dini perlu ditambah juga agar anak usia dini dapat melakukan hal yang berbeda pada meronce sebelumnya dengan menggunakan media meronce yang berbeda. Dari kesimpulan refleksi di atas maka diadakan siklus kedua untuk meningkatkan hasil yang diperoleh anak usia dini sehingga penelitian ini dapat dikatakan

Jurnal Pelangi Jurnal pemikiran dan penelitian pendidkan Islam anak Usia Dini 
berhasil. Pada siklus kedua keterampilan motorik halus meningkat menjadi $71 \%$ dikarenakan pada siklus ini anak-anak usia dini sudah merasakan kesenangan belajar keterampilan motorik halus ini dengan menggunakan meronce ini, sehingga dapat disimpulkan secara kualitatif bahwa meronce dapat meningkatkan keterampilan motorik halus anak usia dini kelompok A Taman Kanak-Kanak Aisyiyah (TK) II Tolobali Kota Bima.

Hasil pengambilan data yang dikumpulkan selama kegiatan pra tindakan, lalu pengambilan data di lapangan dari siklus I dan siklus II dapat disimpulkan bahwa kemampuan anak usia dini meningkat, sedang keterampilan motorik halus kelompok A Taman Kanak-Kanak Aisyiyah (TK) II Tolobali Kota Bima meningkat setelah menggunakan kegiatan meronce yang dibuktikan dengan peningkatan prosentase pada setiap aspek yaitu keterampilan motorik halus mencapai $26,8 \%$, setelah dilaksanakan siklus I meningkatkan menjadi $34,8 \%$ dan pada siklus II meningkat lagi menjadi $40 \%$, hal ini disebabkan oleh berbagai faktor diantaranya media yang digunakan menarik anak usia dini sehingga anak usia dini senang melakukan kegiatan meronce. Anak-anak usia dini juga meronce dengan temannya atau bekerja kelompok sehingga mengajarkan anak usia dini untuk bersosialisasi, meronce ini memiliki tantangan yang membuat anak-anak usia dini ingin menyelesaikan kegiatan sampai akhir agar anak usia dini bisa menghasilkan sebuah karya yang utuh. Peneliti melihat pada saat kegiatan meronce ini berlangsung anak-anak usia dini sangat antusias dan bersemangat pada saat mereka meronce.

Menurut Piaget dalam Diana permainan merupakan salah satu media yang memungkinkan anak usia dini mempraktikkan kompetensikompetensi dan keterampilan-keterampilan yang diperlukan dengan cara yang menyenangkan. Kegiatan pembuatan ini juga melatih gerak otot tangan anak usia dini sehingga mereka memiliki kemampuan untuk menempel, membentuk, dan menyusun dengan benar. ${ }^{16}$

Keaktifan anak-anak usia dini dalam mengikuti kegiatan tersebut tak lepas dari peran serta guru yang sangat dibutuhkan oleh mereka. Anak-anak usia dini terlebih dahulu mendengarkan langkah-langkah

\footnotetext{
${ }^{16}$ Diana E Papalia dkk, Human Development (Perkembangan Manusia) Edisi ke 10 (Salemba Humanika:2009)
} 
kegiatan yang dijelaskan oleh guru sebelum memulai kegiatan. Menurut Vygotsky, anak-anak usa dini sangat membutuhkan pengaruh-pengaruh sosial berupa instruksi yang membantu perkembangan kognitif mereka. Pada saat anak-anak usia dini melakukan kegiatan yang lebih rumit untuk diselesaikan sendiri dari sebelumnya, mereka akan meminta bimbingan dan bantuan dari guru atau teman-teman lain yang lebih terampil. ${ }^{17}$

Kegiatan meroncemerupakan salah satu kegiatanyang menyenangkan untuk meningkatkan keterampilan anak usia dini. Dengan kegiatan meronce membuat anak- anak usia dini senang mengasah keterampilan motorik halusnya dan tidak terlalu bosan dalam melakukan kegiatan di dalam kelas. Media menunjang juga membuat anak usia dini lebih cepat dalam meningkatkan motorik halus karena media yang digunakan juga media yang dekat dengan anak usia dini.

\section{KESIMPULAN}

Prose pembelajaran berawal dari guru menyediakan media meronce yang digunakan untuk menunjang dan melaksanakan kegiatan meronce dan diikuti oleh anak-anak, usia dini memfokuskan untuk meningkatkan mampu mengelompokkan, memasangkan benda yang sama dan sejenis atau sesuai pasangannya, menyusun kepingan hingga menjadi bentuk utuh, dan membedakan beragam ukuran. Mengulang melakukan kegiatan meronce meningkatkan keterampilan motorik halus anak usia dini, evaluasi dilakukan dengan observasi, pengamatan dan juga beberapa wawancara. Peningkatan keterampilan motorik halus anak usia dini kelompok A Taman Kanak-Kanak Aisyiyah (TK) II Tolobali Kota Bima meningkat setelah menggunakan kegiatan meronce yang dibuktikan dengan peningkatan prosentase pada setiap aspek yaitu keterampilan motorik halus mencapai $26,08 \%$ setelah dilakukan siklus I $34,8 \%$ dan pada siklus II meningkat lagi menjadi $40 \%$.

${ }^{17}$ Santrock, John W. 1995. Life-SpanDevelopment, Perkembangan Masa Hidup. Jakarta: Erlangga.

Jurnal Pelang̉i Jurnal pemikiran dan penelitian pendidkan Islam anak Usia Dini 


\section{REFERENSI}

Anne V. Gormly and David M. Brodzinsky, lifespan Human Development, Fifth Edition (New York: Harcourt Brace Jovanpviich College Publishers, 1993: 167).

Bambang Sujiono, dkk., Metode Perkembangan Fisik, ( Jakarta: Universitas Terbuka, 2010).

Diana E Papalia dkk, Human Development (Perkembangan Manusia) Edisi ke 10 (Salemba Humanika: 2009).

Desmita,PsikologiPerkembangan,(Bandung:PT Remaja Rosdakarya, 2008)

Gallahu, David L. dan John C. Oznum. Understanding Motor Development. Boston: MC Graw Hill Ccompanies. 1998: 20).

Ika Setia Endayanti, "Meningkatkan Kemampuan Motorik Halus Melalui Kegiatan Meronce Pada Anak Kelompok Bermain Masjid Syuhada", ("Skripsi”, Universitas Negeri Yogyakarta, 2013), 33.

Kemmis, Stephen and Robin Mc Tanggart, Action Research Planner (Victoria: Deakin University Press,1988).

Mumpuni Arum Bakti, "Peningkatan Keterampilan Motorik Halus Melalui

Kegiatan Meronce Menggunakan Tanah Liat Pada Kelompok B TK Yayasan Masyithoh Beran Bugel Kulon Progo", ("Skripsi", Universitas Negeri Yogyakarta, 2014), 46.

Santrock, John W. 1995. Life-SpanDevelopment, Perkembangan Masa Hidup. Jakarta: Erlangga.

Santrok W John Perkembangan Anak, Edisi Kesebelasan Jakarta: Penerbit Erlangga, 2007: 16).

Susi Sudaryani, "Penerapan Tehnik Meronce Untuk Mengembangkan Kreativitas Anak Di Kelompok B1 Raudhatul Athfal Babul Janah Bengkulu", ("Skripsi", Universitas Bengkulu, 2014), 26. 